\title{
The Politics of Military Transition Programmes to Democracy in Nigeria, 1966-1999
}

\author{
OluAwofeso, Ph. D \\ Department of Political Science, Obafemi Awolowo University, Ile-Ife, Nigeria.
}

\begin{abstract}
The literature on the activities of the Nigerian military since independence is unquestionably copious. However, while many of these works centred on military coups and intervention on politics, civilmilitary relations, transition to civil rule programmes, etc., few actually analyse the political intrigues or schemes surrounding these activities. This article is an attempt to fill some of these gaps, especially in the area of military transition programmes to civil rule in Nigeria. This paper against this background X-rays all the military transition to civil rule programmes since 1966 till date, and attempted a critical analysis of them with the view tounveiling the politicisation these transition programmes were subjected to. The study reveals for instance, the calculated attempt at using military transition programmes to transform erstwhile military Heads of state to civilian president during the Babangida and Abacha regimes; as a strategy for 'safe exist' for erstwhile military rulers; and a ploy for the military to return to power by handling over power in chaos as experienced during General Babangida transition to democracy
\end{abstract}

Key word: Politics, Military Transition Programme, Democracy, Military Coup

\section{INTRODUCTION}

It was most fashionable in Nigeria for a military regime after dislodging a civilian authority, or staging and successfully implementing a counter coup, to announce a programme of action that will lead to final disengagement of the military from political scene. This at first sounds authentic as global trends towards democratization forbids military regime, as such regimes are compelled to a 'brief' stay in office. On the other hand, it could result into being a well taught, carefully calculated stepping stones toward perpetuating the military in power through manipulations and later, contest for a national election. In this case, the military needed time to carry out its ulterior motives. In order to gain time the military had to legitimize itself and the announcement of a transition programme to civil rule is one of the many ways the military legitimizes its stay in office.

Our discussion of military disengagement from politics shall focus on the Nigerian experience. Before this, let us quickly examine types of military disengagement from politics and see the category the Nigerian experiments fall.

\section{Types of Military Disengagement}

Based on scattered evidences and available cases of military transition programmes to civil rule in a number of African countries, BayoAdekson (1979), identifies three basic types of military disengagement. These are:

\section{The Counter Coup-Inspired Approach:}

This occurs when the incumbent military leaders showed no interest of relinquishing power to the civilian, or when there exists sharp disagreement among the ruling junta over relinquishing power, or over dates of final disengagement of the military. Under this situation, the only possible alternative to a stay-tight military dictatorship is a counter coup, often backed with popular revolt to effect a transitional change to civil rule. Gowon, Idi-Amin and Mobutu military regimes in Nigeria, Uganda and former Zaire respectively were cases in point.

\section{The Military-Turned-Political Pattern:}

This is a case of an incumbent military, the Head of State transforming himself through various manipulations, to civilian president. Puts differently, it is a case of "a surface change from men-in-uniform (Khaki) to soldiers in-mufti (Agbada)". Here the erstwhile military leader having manipulated in his favour, mass support for his continuous stay in office, party formation and their activities etc, self-appointedly contests for national election. And of course, he uses all the state apparatus to ensure his victory. In Africa, there are many cases of erstwhile military leaders contesting and wining presidential election. Jerry Rawlings and Samuel Doe were good examples of Ghana and Liberia respectively. Cases of military-turned-civilian pattern are also common in most Francophone Africa. This include: “Lamizana's Upper Volta, Eyadema's Togo, Bakassa's Central Africa Empire, and Mobutu's Zaire”. At the tail end of the Abacha's regime, there were speculation and indication that he would transform to civilian president, but the pattern it would take was not known till his death in office. 


\section{The Constitutional Evolutionary Model:}

The Military under this pattern fully disengages from political scene and relinquishes power to democratically elected civilians. Usually, a programme of action or transitional time-table to civil rule is announced and religiously implemented in phases or stages. Such programme may feature "processes as the making of a new constitution, summoning of a constituent assembly to debate and ratify the draft constitution, lifting of ban on political party activities and finally the holding of national election to determine the civilian successors to the military". Both the Mohammed/Obasanjo (1976-79) and the Abubakar (1998-99) transition programmes to civil rule in Nigeria are clear examples of the constitutional evolutionary model. In both cases, the military had a transition time-table which was religiously adhered to until the final hand-over date as stated in the time-table.

It should quickly be noted here that these three classificatory schemes are not in themselves individually autonomous without sometimes consisting elements of others. Otherwise these classifications are tentatively done based on observable pattern of demilitarization.

\section{Military Transition Programmes to Democracy in Nigeria}

It is a common practice for most military regimes in Nigeria to hurriedly announce a programme of action that will lead to final disengagement of the military from political arena. Experiences have however shown that promises of total hand-over to civilians in most cases lacked genuine commitment. Of all the military transition programmes in Nigeria, only two-the Mohammed/Obasanjo's own and that of Abubakar were successful, while General Babangida's civil rule ended up in a fiasco. The Ironsi's transition programme to civil rule never saw the light of the day, while Gen. Gowon's efforts were self aborted. Abacha's transition programme was inconclusive. We can quickly and briefly examine each of these transition programmes to civil rule.

\section{Ironsi's Attempted Transition Programme to Democracy}

Needless to reiterate the fact that General Ironsi attempted efforts to return the country to civil rule never saw the light of the day. Suffice to say Ironsi actually attempted as earlier promised to put in place a programme of action that would return the country to a civil system. Shortly after assumption of office, Ironsi set up two Commissions - the Constitutional Review Commission and Administrative Review Commission. The commissions were headed by Chief Rotimi Williams and Mr. F. Nwokedi respectively.

On the political scene, the constitutional review commission was primarily charged with the responsibility of identifying "the constitutional problem in the context of one Nigeria", the recommendation of which would be submitted to a Constituent Assembly, and followed by a referendum. At its inauguration by Ironsi, the commission's terms of reference were stated thus:

1. To identify those faults in the former constitution of Nigeria which militated against national unity and the emergence of a strong central government.

2. Without prejudice to the scope of paragraph (1) above:

a. To ascertain to what extent the power of the former regional governments fostered regionalism and weakened the central government

b. To ascertain what extent the structure and in particular the territorial division of the country under the former constitution contributed to the deficiencies of the former regime.

3. To consider the merits and demerits of:

a. A unitary form of government

b. A federal form of government

4. In the light of paragraph (3) above to suggest possible territorial division of the country.

5. To consider the merits and demerits of:

a. One party system

b. Multi-party system as a system best suited to Nigeria.

6. To examine the voting system, Electoral Act and provision of voter's register.

7. To determine to what extent party politics fostered tribal consciousness, nepotism and abuse of office.

8. To determine to what extent professional politics contributed to the deficiencies of the past regime.

9. To determine the extent to which regionalism and party politics tended to violate traditional chieftaincies and institutions and to suggest possible safeguards.

The other commission headed by Nwokedi submitted its report before the Williams commission could even start serious deliberation. The Ironsi administration based on Nwokedi's report went ahead to announce on 24 May, 1963 the following far-reaching political and administrative changes.

i. The administrative class of the various civil services was to be unified;

ii. The existing regions were to be abolished and in their place there would be groups of province;

iii. Regional military governors were to be replaced by military governors of group of province; and

iv. Military prefects would be appointed and would be in charge of various provinces.

Subsequent decisions and action of the administration following the above declaration, coupled with prevailing political circumstances led to the assassination of Ironsi in a military coup. For instance, Ironsi's transformation of Nigerian federal structure to unitary system through Decree No. 34 of 1966, his refusal or delay to bring to book the leaders of the January, 1966 coup many of which were Ibos and which had several Northern leaders as casualties, etc, may have prompted a counter coup in July, 1966. It is difficult to classify 
categorically the Ironsi attempted efforts under any of the three types of military disengagement. Why? Because the administration's duration was too short to be subjected to any objective assessment.

\section{Gowon's Aborted Transition Programme to Civil Rule}

Shortly after the Nigerian civil war in 1970, Gowon announced a 9-point transition programme, which was supposed to terminate in 1976. The programmes are as follows:

1. Reorganization of the Armed Forces.

2. Implementation of the National Development Plan and repair of war damage.

3. Eradication of comuption in Nigeria's national life.

4. Creation of more states.

5. Preparation of a new constitution.

6. Fashioning a new Revenue Allocation Formula.

7. Conducting National Population Census.

8. Organization of genuine national political parties.

9. Conducting elections into state and federal offices.

It is worth mentioning here that of all the 9-point programme mentioned above, four were not touched at all. These are: creation of more states, preparation of a new constitution, formulation of new political parties and the conduct of elections into state and federal offices. On the issue of comuption, it is difficult to give the administration a pass mark, as senior military officers and highranking bureaucrats lived in affluence in the face of abject poverty showered on the masses, despite the oil boom. Surprisingly, Gowon on October 1, 1974 came up with flimsy excuses and announced to the bewildered Nigerian populace that the 1976 hand-over date was unrealistic. According to him: Four years ago when I gave 1976 as the target date for returning the country to normal constitutional government, both myself and the military hierarchy honestly believed that by that date, especially after a bloody civil war... there would have developed an atmosphere of sufficient stability... 1976 is unrealistic, it would indeed amount to a betrayal of trust to adhere rigidly to that target date.

The Gowon transition programme is more of counter coup inspired disengagement than other two types of disengagement. Although, the administration initiated a transition programme which was to usher in civilian administration in 1976, its indecision over relinquishment of power and perhaps deliberate attempt to stay-put invited a counter coup. Dudley (1982), for instance observes that the administration was to proclaim 'Nigeria a one-party, with the party centredaround General Gowon who would become president". This observation looks real, especially when viewed against the background of the fact that as early as 1972 "some members of the bureaucracy were sent to Egypt, Zaire and Guinea to study the system in these states as possible models for a Nigerian one-party state'. It was therefore not surprising that it was Gowon's government failure to renege on hand over to civilian in 1976 that stimulated a coup that overthrew it on July 29, 1975.

\section{The Mohammed/Obasanjo Transition Programme to Democracy}

The Mohammed /Obasanjo administration had a well formulated time table of transition to civil rule. The time table was divided into phases, each of which was expected to initiate and execute programme of action that will lead to the final disengagement of the military from political scene. These programmes of action include:

Phase 1: Creation and establishment of new states (August 1975-April 1976), constitution drafting (October 1975-September 1976).

Phase 2: Local government reorganization, reforms and elections, summoning of a constituent Assembly to deliberate on draft constitution (September 1976-October 1978).

Phase 3: Electoral constituencies delimitation, lifting of ban on political parties activities (October 1978).

Phase 4: Holding of elections to legislative and executive offices at the state level.

Phase 5: Holding of elections to legislative and executive offices at the federal level and handover of power by October $1^{\text {st }} 1979$.

A further breakdown of the actualization of the programme reveals the following:

- $\quad$ Seven more states were created in April, 1976, bringing the total number of states to 19.

- $\quad$ The local government reform was initiated and adopted in 1976.

- $\quad$ The Constitutional Drafting Committee (CDC) headed by Chief Rotimi Williams submitted its reports in September 1976. The committee was inaugurated in October, 1975 to produce "an initial draft of a constitutional arrangement which could provide a strong basis for the continuing existence of a united Nigeria".

- Elections were held into the newly established councils in December, 1976.

- The inauguration of the Constituent Assembly (CA) took effect in October 1977 and was headed by Justice UdoUdoma. The body was charged with the amendment and final adoption of the new constitution. The body submitted its work to the government in August, 1978.

- $\quad$ The federal military government in September, 1978, lifted ban on political activities.

- The Federal Electoral Commission (FEDECO) was inaugurated in 1978 and was charged with the responsibility of regulating, supervising and conducting elections. 
- In July 1979, Military Governors were replaced by military administrators who served as Caretakers during the period of transition.

- General elections were held on every Saturday between July 7, 1979 and August 1, 1979. The elections were in this order: First was the senatorial election, followed by the House of the Representatives, next was the State House of Assembly, after was the State Gubernatorial elections, and finally, the Presidential election.

- The final handover of political power to a popularly elected government took effect on October 1, 1979.

It is instructive to note that the Muhammed/Obasanjo transition programme was religiously executed to letters with no major alteration in the transition time-table. Most importantly and against public speculation that the military will not relinquish political power to a civilian president, the administration fulfilled its promise by handing over political power to democratically elected civilian president. The Muhammed/Obasanjo method of disengagement approximates the constitution-evolutionary model. The military having implemented all its programme in the transitional time-table to civil rule fully disengaged from political arena and withdrew back into the barracks.

\section{General Babangida Transition Programme to Democracy}

The Babangida transition programme started in 1986 and ended up in a fiasco on August 26, 1993. Unlike the Muhammed /Obasanjo, the Babangida transition programme had no clear-cut time-table. Though, a time-table was later released by the administration, the government in its implementation, swayed from one programme to another with seemingly lack of direction and emptiness derived from lack of articulate programme, and perhaps the insincerity of the administration to relinquish power.

The following programme of action was later released by the Babangida administration:

Schedule 1 - Programme for 1987

$$
3^{\text {trd }} \text { Quarter-1987 }
$$

Establishment of the Directorate of Social Mobilization,

Establishment of National Electoral Commission,

Establishment of a Constitutional Drafting Committee $4^{\text {th }}$ Quarter-1987

Elections into local governments on non-party basis

Schedule 2-Programme for 1988 $1^{\text {st }}$ Quarter-1988

Establishment of National Population Commission

Establishment of Code of Conduct Bureau

Establishment of Code of Conduct Tribunal

Establishment of Constituent Assembly

Inauguration of National Revenue Mobilization Commission $2^{\text {nd }}$ Quarter-1988

Termination of Structural Adjustment Programme (SAP)

Consolidation of gains of SAP $3^{\text {td }}$ Quarter-1988

Consolidation of gains of SAP $4^{\text {th }}$ Quarter - 1988

Schedule 3-Programme for 1989 $1^{\text {st }}$ Quarter-1989

Promulgation of a new constitution

Release of new fiscal arrangements

$$
2^{\text {nd }} \text { Quarter-1989 }
$$

Lift of ban on party politics

$$
3^{\text {rd }} \text { Quarter-1989 }
$$

Announcement of two reorganized and registered political parties

$$
4^{\text {th }} \text { Quarter }-1989
$$

Election into local government on political party basis

\section{Schedule 4-Programme for 1990}

$$
1^{\text {st }} \text { and } 2^{\text {nd }} \text { Quarters }-1990
$$

Election into State legislatures and state executives

$$
3^{\text {rd }} \text { Quarter-1990 }
$$

Convening of State Legislatures

$$
4^{\text {th }} \text { Quarter-1990 }
$$

Swearing in of State executives

Schedule 5-Programme for 1991

$$
1^{\text {st }} \text { Quarter-1991 }
$$

Census 


\section{$2^{\text {nd }}$ Quarter-1991}

Census

$$
3^{\text {rd }} \text { Quarter-1991 }
$$

Census

$$
4^{\text {th }} \text { Quarter-1991 }
$$

Local government elections

Schedule 6-Programme for 1992

$$
1^{\text {st }} \text { and } 2^{\text {nd }} \text { Quarters }-1992
$$

Elections into federal legislatures and convening of National Assembly

$$
3^{\text {rd }} \text { Quarter-1992 }
$$

Presidential Election

Swearing-in of new president and final disengagement by the Armed Forces

It is worth mentioning here that unlike the Muhammed /Obasanjo transition programme, the Babangida administration started its programme of action to civil rule in 1986 before it formerly releases its transitional time-table in July, 1987. Although, the administration implemented all the programmes in its time-table, except of course the last, that is, the swearing in of a civilian president, its time-table programme was subjected to intermittent alterations which in effect culminated into changes in the date of final disengagement of the military.

We can revert to those sequence of decisions and actions taken in order to accomplish the Babangida transition programme.

1. The government inaugurated the Political Bureau headed by Samuel Cookey in 1986 to proffer an enduring political system for the Third Republic. The Bureau among other things recommended a two-party system and the presidential system.

2. In June 1986, the government announced a blanket 10 years ban of all leading politicians and former public offices holders in the first and second republics. The list was further increased in 1987 and 1989. With this development, the term "New Breed Politicians" emerged in Nigerian politics.

3. In 1987, (MAMSER), the Constitution Review Committee (CRC) and National Electoral Commission (NEC) were created. The CRC, a 46 member headed by justice BubaArdo was charged with the responsibility of carrying out a review of the 1979 constitution in light of the accepted recommendation of both the Political Bureau and the committee on Draft White Paper. The NEC headed by Professor Ema Awa (he was later removed and replaced by Professor Humphrey Nwosu) was charged with the responsibility of conducting local government election and subsequent elections.

4. On December 12, 1987, Local Government elections were conducted on a non-party basis.

5. Number of states were increased from 19 to 21 in 1987.

6. The inauguration of National Population Commission (NPC), the Code of Conduct Bureau, the Code of Conduct Tribunal. The Constituent Assembly and the Revenue Allocation Commission, all took off in 1988. The Constituent Assembly headed by Anthony Aniagolu was inaugurated for the purpose of debating and ratifying the draft constitution.

7. On October 7, 1989, the Armed Forces Ruling Council (AFRC) rejected the 6 political parties recommended by the NEC, and in their replacement decreed two new political parties - The National Republic Convention (NRC) and the Social Democratic Party (SDP).

8. On December 9, 1990, local government elections were held on party basis and the open ballot system.

9. On August 27, 1991, 9 new states were created, thus bringing the total number of states to 30.

10. Census was conducted in 1991. Also, elections into state executive and the state legislatures were held. Civilian governors were sworn-in in January, 1992.

11. In 1992, the first two primaries conducted to select presidential aspirants were rigged. The NEC had to intervene. The results of the elections were cancelled, while the 23 presidential aspirants both for the NRC and SDP were banned from contesting future elections. The NEC came up with several options among which option A4 was approved by the AFRC. The open ballot system was also modified.

12. On October 16, 1992, the military government dissolved the executive committee of the two parties at all levels replacing them with caretaker committees. AlhajaLateefOkunnu was appointed the National chairperson for the NRC while Air-Vice marshal IshayaShakari (Rtd) was appointed the national chairman for SDP caretaker committee.

13. On December 5 1992, the National assembly was inaugurated. Dr. IyorchaAyu became the Senate President while Barrister AgunwaKniekwa became the Speaker of the House of Representatives.

14. On December 16, 1992, a 27-man transitional council was named to carry on the day-to-day administration of the country during the transition period. Chief Ernest Shonekan became the chairman of the transitional council, thus he became the first civilian Head of government under a military administration.

15. Following the dissolution of the AFRC, the military president announced the creation of the National Defence and Security Council (NDSC) which replaced the AFRC. President Babangida himself became the chairman of the NDSC while both the Transitional Council and the National Assembly were subordinate to the NDSC. The NDSC was the supreme law-making body.

16. Between December 1992 and February 1993, more than 240 new aspirants had made known their interests to contest in the new primaries to be based on the option A4 formula and the modified open ballot system.

17. Between February 6 and March 26, 1993, parties congresses based on option A4 and open-secret ballot system, were held at various levels to select the presidential flag bearers for both the NRC and SDP, local government and state congresses were held 
on February 6, February 20 and March 6, 1993, respectively for the two parties. The national congresses were conducted on March 28, 1993 in Jos for the SDP and Port Harcourt for the NRC. Both Chief M. K. O Abiola and Alhaji Bashir Tofa finally emerged the party flag bearers for SDP and NRC respectively.

18. Following the election of the flag bearers of the two political parties, campaign for electorate supports were embarked upon by the two parties. The presidential election was finally conducted on June 12, 1993.

19. On June 23, 1993, the Babangida administration annulled (cancelled) the results of the June 12, 1993 election and insisted that another election be conducted before August 27, the final date of military disengagement in politics. This of course led to a protracted political crisis in Nigeria.

20. Between June 23, and August 25, 1993, Nigerian political landscape was beclouded by severe political tension. The country was at a brink of a total collapse. There were threats of secession, disintegration and war. Subsequent events later revealed that the NRC and a faction of the SDP were sold the idea of an Interim National Government (ING) as the only viable solution to the political impasse. Meanwhile the Association for Better Nigeria $(\mathrm{ABN})$ led by Author Nzeribe was busy campaigning for the extension of the Babangida administration by more years.

21. On August 26, 1993, the Babangida administration imposed an illegitimate ING to complete its uncompleted transition programme. Meanwhile, General Babangida government "stepped aside".

It is instructive to note here as earlier mentioned that except the last item on the Babangida transition time-table, every other items were fully implemented. This however raised the question of insincerity on the part of the administration to relinquish power to a civilian president. It also goesa long way to buttress the allegation of a "hidden agenda" nursed by the regime to perpetuate the military in office, as confirmed by the administration's continuous alteration of the time-table and postponing for at least three times the handover-date - first from 1990 to 1992, next to January, 1993 and finally August, 1993. In contrast to the Muhammed/Obasanjo transition programme, and contrary to the Babangida regime promises, the administration only succeeded in handling over power to undemocratically elected group of people otherwise, tagged Interim National Government after about 7 years of political sojourn and socio-economic engineering. It could be recalled that it took the Muhammed/Obasanjo regime only three years to successfully and completely disengaged from political scene, both Gowon and Babangida could not do the same in 9 and 8 years respectively: and while the former was forcefully removed by a military coup, the later was forced to relinquish power unceremoniously without accomplishing military disengagement to its fullest.

Whereas, the Muhammed/Obasanjo transition programme seemed to have confined and focused itself with political issue: creation of states, promulgation of a new constitution etc, while the Babangida transition programme which touched all phases of sociopolitical and economic engineering where "elaborate political and economic reforms or restructuring are pursued simultaneously as necessary conditions to consolidate the democratic process". Besides, the programmatic focus of both administrations seems to differ. The Babangida regime seemed to have been more concerned with how to institutionalize an enduring political culture congruent with a stable democracy. Hence, the administration priority and emphasis during the transition period was how to effect a participative political culture in the attitudinal dispositions of the people through agencies like MAMSER, DIFRRI and Better life. The same goes to the government decision to ban old politicians from participating in politics. That also explains the need for a viable economic congruent with stable democracy; hence, the administration economic restructuring policy of Structural Adjustment Programme (SAP).

Similarly, the Babangida regime seemed to have over involved itself in things which it should otherwise have remained neutral. Otherwise, what business does a transitional military regime has with formation of political parties, funding of parties activities including erection of secretariats, writing of parties manifestoes and ideologies, specifying parties emblems. All these according to the critics of the regime are conscious strategies carefully planned and executed to elongate the military power, as those political programmes that could lead to the final disengagement of military were haphazardly implemented. On the other hand, the transitional style of successive military regime to civil rule in Nigeria has always been the same, the only difference being in their programmatic focus, priority and emphasis. In the first place transition programmes to civil rule in Nigeria have always been from the military rule to multi-party politics, or an attempt to achieve that, unlike in Cape Verde in 1990, Benin Republic and Zambia in 1991 where transition was from one-party rule to multi-party democracy. Another form of transition which is "less concerned with coordinated economic and political restructuring model" as experienced in Nigeria and Ghana, is common in the Francophone countries. It is the national conference model. "Its major focus is on wringing constitutional concessions from and ultimately rendering important and removing embattled dictatorial rulers like Mathieu Kerekou in the Benin Republic, GnasisingbeEyedema in Togo, DenisSassouNguesso in Congo-Brazzaville".

Right from the Gowon to Abacha transition programmes successive military regimes had taken, at least at initial stage, the Constitutional-Evolutionary model with the initiation of transition time-table with similar programme: creation of more states, reorganization of local government, conduction of census, implementation of far-reaching administrative reforms, adoption of a new constitution and lifting of ban on political activities. It is difficult to classify the Babangida transition programme exclusively under any of the three typesof military disengagement because it exhibits certain elements of them all. The announcement of a transition time-table and subsequent implementation of almost all its items may have initially qualified it as a Constitutional-Evolutionary Model. However, subsequent actions of the regime later revealed its "hidden agenda" to perpetuate itself in office. The indiscriminate alteration of the transition time-table, skilful initiation and implementation of diarchism, and the unchecked activities of the Association for Better Nigeria and the annulment of presidential election, all seemed to unveil an ambitious leader scheming to succeed himself in a militaryturned political pattern of disengagement. At another extreme, the regime was forced to relinquish power against its wish, though not 
through a counter coup, the singular characteristics of no intention to relinquish political power to civilian seemed to have approximated the counter coup-inspired approach of disengagement. In all, the regime type of disengagement seem to have weighed towards the Constitutional-Evolution model than the other two.

\title{
From Child of Necessity to Succession Bid: The Abacha Transition Programme to Democracy in Nigeria Background
}

The circumstances that brought General Abacha to political power on November 17, 1993 can be traced back to the annulment of the June 12, 1993 Presidential election by the Babangida regime, and the subsequent transfer of power to a Caretaker Government, the Interim National Government (ING), headed by Chief Earnest Shonekan. The ING was imposed on Nigerians to conclude the inconclusive aspects of the Babangida transition to civil rule programme. Expectedly, the Shonekan led ING could not fulfill this objective; neither could it maintain law and order. The government was lacking in legitimacy and had to cope with the volatile issue of increased price of petroleum, incessant strikes organized by the Labour Union, non-recognition of the Head of State by some State Governors who "refused to come to Abuja to meet the new Head of State", etc. The magnitude of general breakdown of law and order was succinctly put in the words of justice Nasir, the chairman of the Transition Implementation Committee under Abacha in his observation that: Is there any breakdown of law and order more than this one where the Head of State can't go home? He (Chief Shonekan) was being stoned in his home-town. And when General Abacha eventually struck by forcing Chief Shonekan to tender his resignation in a bloodless coup, he christened his new military government as "a child of necessity" brought about by the circumstances discussed above. In his nationwide coup speech on November 17, 1993, General Abacha remarked that: This government is a child of necessity. With the strong determination to restore peace and stability to our country, and on this foundation and through a lasting and true democracy. Give us the chance to solve our problems in our own ways.

The following decisions announced in the coup speech actually established a change of government.

- The Interim National Government is hereby dissolved.

- The National and States' Assemblies are also dissolved.

- The States' Executive Councils are dissolved. The brigade Commanders are to take over from the Governors in their states until administrators are appointed. Where there are no Commanders, the Commissioners of Police in the states are to take over.

- $\quad$ All Local Governments stand dissolved. The Director of personnel are to take over the administration of the local governments until Administrators are appointed.

- $\quad$ All former Secretaries to Federal ministries are to hand over to their Director-General until Ministers are appointed.

- The two political parties are dissolved. All processions, political activities, associations of any kind in any part of the country are hereby banned. Any consultative committee by whatever name called is hereby proscribed.

- $\quad$ Decree 61 of 1993 is hereby proscribed.

- A provisional Ruling Council is hereby established. It will comprise the Head of State and Commander-in-Chief of the Armed Forces of Nigeria as Chairman, the Chief of General Staff as Vice-Chairman, the Honourable Minister of Defence, the Chief of Defence Staff, Service Chiefs, the Inspector-General of Police, the Attorney General and Minister of Justice, the Internal Affairs Minister, the Foreign Affairs Minister and the National Security Adviser.

General Abacha did not announce his transition programme until October 1, 1995, about two years after he ascended political authority. However, the administration had in May, 1994 inaugurated a constitutional conference composed of elected 'representatives' to the people to discuss and make recommendation to the PRC on various issues of political relevance that would govern the emergence of the new political dispensation. One year later, the conference submitted his report as well as a draft constitution. The Abacha transition time-table reads thus:

\author{
The Time-Table \\ 1995 Last Quarter-October-December \\ 1. Approval of Draft Constitution. \\ 2. Lifting all restrictions on political activities. \\ 3. Establishment of the National Electoral Commission of Nigeria (NECON). \\ 4. Creation of: \\ a. Transition Implementation Committee \\ b. National Reconciliation Committee \\ c. Federal Character Commission \\ 5. Appointment of Panel for creation of States; Local Government; Boundary Adjustment. \\ 1996 First Quarter-January-March \\ Election and inauguration of Local Government Councils on Non-Party basis. \\ 1996 Second Quarter-April-June \\ 1. Creation of States and Local Governments. \\ 2. Commence process of political party registration. \\ 1996 Third Quarter-July-September \\ Election of Local Government Councils on Party Level.
}


1997 First Quarter-January-March

1. Inauguration of party elected Local Government Councils.

2. Consolidation of new Political Party Structures.

3. Tribunal sitting and conduct of any Local Government Bye Elections.

1997 Second Quarter-April-June

1. Party-State Primaries to select Candidates for State Assembly and Governorship Elections.

2. Screening and approval of candidates by the National Electoral Commission of Nigeria.

1997 Third Quarter-July-September

1. State Assembly Election

1997 Fourth Quarter-October-December

1. Election of State Governors.

2. Sitting of the State Election Tribunals and conduct of Bye Elections.

1998 First Quarter-January-March

1. Inauguration of State Assembly and State Governors.

2. Party primaries to select candidates for national assembly election.

3. National Assembly election campaigns.

\section{Second Quarter-April-June}

National Assembly elections

1. Primaries to select candidates for Presidential elections.

2. Commencement of nationwide campaign for the Presidential election.

1998 Third Quarter-July-September

1. Presidential Elections.

$1^{\text {st }}$ October, 1998

Swearing-in of a new elected President and final disengagement.

\section{Implementation}

Following the release of the regime's transition time-table in October, 1995, the Abacha government took far-reaching policy action to implement the items on the time-table. It should be noted that the time-table frame for implementation in most cases was not strictly adhered to. For instance, primaries were expected to have been conducted in the second quarter of 1998 to select candidates for the presidential election, this never took place till the death of Abacha. Also, the creation of state and local government came much later after the specified period in the time-table. All-the-same the following actions were taken by the Abacha regime towards executing its transition programme:

- $\quad$ On October 1, 1995, the government lifted ban on political activities. Following this action, several political associations seeking for registration as political parties in the new dispensation emerged. During the usual horse trading among politicians and political associations, there were merging, alliances and re-alignments which eventually produced about 15 political associations.

- Following the verification exercise of claims of the 15 political associations seeking registration, the National Electoral Commission of Nigeria (NECON) on September 30, 1996 published the performances of all the political associations. Only 5 the United Nigerian Congress Party (UNCP), the Democratic Party of Nigeria (DPN), the Congress of National Consensus (CNC), the National Centre Party of Nigeria (NCPN), and the Grassroots Democratic Movement (GDM) were accredited and thus registered.

- On October 1, 1996, a total of 183 Local Governments and 6 more States were created, thus bringing the number of Local Governments and States to 774 and 36 respectively. The States created were Bayelsa State from Rivers State, Ebonyi State from Abia and Enugu State, Nassarawa State from Plateau State and Zamfara State from Sokoto State.

- Following the conduct of various primaries, elections were conducted into Local Councils, State and National Assemblies, as well as State Governorship.

- The commencement of primaries for the selection of the presidential candidates culminated into nomination of General SaniAbacha by all the five political parties on April 25, 1998.

- Meanwhile, various individuals, mostly agents, sycophants and apologists of the Abacha including the Youths Earnestly Ask for Abacha (YEAA) have taken over the process of the campaign for presidential election, calling for Abacha to transform himself into a civilian president or at best, contest the presidential election as the only candidate.

- General Abacha's death on June 8, 1998 automatically brought the entire process of the Abacha's transition programme to a halt.

\section{The Succession Bid}

Although, General Abacha did not at any point in time openly declare his intention to succeed himself as a civilian president come 1998, events before and after his death seem to support the popular view that the General had a hidden agenda to transform himself into a civilian president. However, Nigerians and the world at large were not given the opportunity to witness the form his transmutation was to assume because of his sudden death in office. We however wish to highlight those events and evidences that made political analysts convinced of the inordinate ambition of General Abacha to stay-put in office. 
- General Abacha was seen to be an ambitious soldier who had his hands in most successful coups since 1983 in Nigeria. Having been in the political cum military for over 15 years, the highest political office ever attained was his post as the "deputy-incommand" to the former Head of State, General Babangida. Although, General Abacha held this post for 8 years, it appears his desire for power was yet to be self-actualized. That explains why he was at the fore front of those military officers who supported the annulment of the June 12, 1993 presidential election. General Abacha was later accused to have led some high ranking senior military officers who held hostage their Commander-in-Chief, General Babangida over the issue of handling over power to the civilian government. In an interview published in the New York Times on Sunday, 26 July, 1998, General Babangida was quoted to have said: "You delegate authority but you do not delegate responsibility". To this, his son, Mohammed who was present during the interview added:

'They put my father in a corner; they threatened him... there were other generals, including late SaniAbacha, who said that if power was ceded to a Southerner like Chief MoshoodAbiola, the North would have nothing left.'

- It was alleged that there existed a secret pact between General Babangida and General Abacha over the issue of relinquishment of power by the former to the latter after some years. This theory seem to have been buttressed with the fact that, General Abacha was intentionally left behind as the Defence Secretary in the ING, the body which succeeded the General Babangida regime, while other senior military officers were compulsorily retired by General Babangida. It is believed that General Abacha was intentionally left behind to forcefully take over power from the Shonekan led caretaker government. Besides, a clause in the decree that established the ING specified that the most senior officer (who incidentally was Abacha) in the government will assume political authority where the office of the Head of State became vacant for one reason or the other. And when he eventually took over power, General Abacha against all expectations and opportunity to reverse the presidential annulment by respecting the June 12, 1993 mandate, went ahead to form his own government and threatened to deal ruthlessly with any opposition to his government. Hear his threat in his coup speech of November, 1993.

This regime will be firm, humane and decisive; it will not condone or tolerate any act of indiscipline. Any attempt to test our will, will be decisively dealt with.

- Following his declaration as the legitimate president of Nigeria in June 1994, Chief M. K. O Abiola, the acclaimed winner of the June 12, 1993 presidential election was arrested and incarcerated by General Abacha. Every plea to release Chief Abiola, both internal and international fell on his deaf hears. Not even, the intervention of Pope John II on behalf of Abiola could release him. General Abacha was only willing to release Chief Abiola on the condition that he denounces his mandate.

- General Abacha reign of terror and assassination of perceived opponents and potential contenders to the office of presidency was to pave the way for a rare image of an all-knowing best leader who must be persuaded to remain in office. Prospective candidates for presidency were either eliminated, imprisoned or forced into exile to clear the coast for smooth transmutation.

- The registration of political parties was crudely manipulated that only the political associations formed by General Abacha's agents and supporters were registered, while other political associations formed by notable radicals and progressives were not registered. Events later showed that all the five political parties nominated General Abacha as their consensus candidate for the presidential election.

- The Abacha regime allowed and secretly sponsored the Daniel Kanu led Youths Earnestly Ask for Abacha (YEAA) to continue its campaign for Abacha's continual stay in office which culminated into the organization of the so called two-million man march organised under the umbrella of National Council of Youth Association of Nigeria (NACYAN). The same government dissupted a similar rally organised in Lagos by United Action for Democracy (UAD) to oppose the NACYAN's rally in Abuja.

- In less than three months to the presidential election, in a country with over 120 million population with highly tested and experienced politicians and eminent personalities with abundant knowledge of international repute, only the military warlord in person of General SaniAbacha, was seen to be qualified by the five political parties to rule Nigeria. Abacha in his usual manner kept mute and pretended not to be interested in succeeding himself, that he was only being forced to. The coast was already cleared for Abacha to succeed himself. It was only a matter of time. However, death never allowed that time and opportunity to materialize. And so we were left in the dark to know how Abacha would have transformed himself to a civilian president.

- Further revelation at the Oputa panel by General Abacha whose associates had confirmed that Abacha purposely created a chaotic political atmosphere to ease his way to self-succession as attested to by active participants of hi regime of terror.

\section{General Abubakar Transition Programme to Democracy Background}

The sudden death in office of GeneralSaniAbacha, the erstwhile military dictator and Head of State, on June 8, 1998 paved the way for General AbdulsalamiAbubakar as the Nigerian new military Head of State on June 9, 1998. Initially, there appeared to be what looks like a problem of leadership succession among the high ranking senior military officers like General IshayaBamuiyi, Abacha's Chief of Army Staff, General Jeremiah Useni, Abacha's Minister of Federal Capital Territory, etc. The choice of General Abubakar, Abacha's Chief of defence Staff, was based on several factors among which were his non-occupation of political office and strict adherence to military professionalism throughout his military career. It took the Abubakar regime few weeks to announce its transition to civil rule programme. In fact, the prolonged problem over the actualization of the June 12 mandate, and the persistent struggle and demand by the pro-democracy groups and Human Rights Organization for the release of Chief M. K. O Abiola from detention to head a government of National Unity, made the new military regime indecisive. The sudden death of Chief M. K. O Abiola in detention on July 7, 1998 slowed down the pace for the actualization of the June 12, 1993 mandate, while GeneralAbubakar 
in his nation-wide broadcast on July 20, 1998 put a final seal to this agitation. According to him: This administration has also given considerable thought to the calls for a Government of National Unity (GNU). We note the patriotic moves of these calls. But such an arrangement is full of pitfalls and dangers which this administration cannot accept... a Government of National Unity whose composition could only be through selection would be undemocratic... we will not substitute one undemocratic institution for another.

Based on the above, General Abubakar announced the cancellation of all the political structures initiated and elections conducted under the Abacha regime on grounds of "their widespread lack of credibility and acceptability". Thus all the existing five political parties were dissolved and their assets taken over by the government, while all elections previously conducted under Abacha's transition to civil rule programme were cancelled. Equally dissolved were the National Electoral Commission (NECON), the Transition Implementation Committee (TIC), the Committee on Devolution of Powers (CDP) and the National Reconciliation Committee (NARECOM). Meanwhile, the Abubakar regime had released all political detainees and charges against them withdrawn. The regime had equally granted pardon to General OlusegunObasanjo and Major-General ShehuYar'Adua over the 1995 phantom coup.

The General then pleaded for time to enable his administration conduct fresh elections and handover power to a new democratically elected government come May 29, 1999 with the promise that his "administration has no desire whatsoever to succeed itself and is steadfastly committed to an expeditious handover to a democratically elected government".

\section{Towards Disengagement}

- Following the General Abubakar nationwide broadcast on July 20, 1998 which cancelled all the existing political structures and elections conducted during the Abacha regime, the same speech advised Nigerians to form new political association that will be registered by a new electoral body.

- A new electoral body, Independent National Electoral Commission (INEC) headed by Professor Ephraim Akpata was established to have responsibility for the "registration of political parties, registration of voters" and conduct of election at every stage.

- In the course of its assignment, INEC carried out delimitation of electoral wards during which 8, 810 electoral/wards were delimitated.

- $\quad$ The INEC registered three political parties the Peoples Democratic Party (PDP), the Alliance for Democracy (AD) and the All People's Party (APP) from the 9 Political Associations that scaled through the first process of Political Party Registration. The registration of the three parties was based on their electoral performance in December 5, Local Government election.

- A 23-member Constitution Debate Coordinating Committee (CDCC) headed by Justice Niki Tobi was set up to coordinate debate on the 1995 Draft Constitution.

- The rejection of the 1995 Draft Constitution and the promulgation of a new constitution (1999) based on the 1979 Constitution with little amendments.

- The INEC successfully conducted elections into various tiers of government - the local government on December 5, 1998, the Governorship and State Assembly elections on January 9, 1999, the National Assembly election on February 20, 1999 and the Presidential election on February 27, 1999.

- General AbdulsalamiAbubakar handed over power to a democratically elected President, General OlusegunObasanjo (Rtd.) on May 29, 1999 at the Eagle Square, Abuja.

\section{The Politics of Transition Programmes to Democracy in Nigeria}

One major aspect of military transition programmes to civil rule that is rarely analyzed in Nigerian politics is how successive military regimes have manipulated their transition programmes to achieve their selfish desires. Thus, transition to civil rule programmes as experiences had shown in Nigeria were political strategies often used by the military to legitimize itself, co-opt the political class and perpetuate itself in office. It is instructive to note that one major strategy the Babangida regime used to legitimize its regime in the face of intense criticism against persistent military rule at the beginning of its administration was the promise to relinquish power through a transition programme to civil rule, the absence of which incidentally led to the criticism of his predecessor, General Buhari who was never in a hurry to announce any programme of transition to democracy. The same transition programme was manipulated by General Babangida to perpetuate himself in office by continually extending the final disengagement date, first from 1990 to 1992, and later to 1993. In the case of Abacha's regime, having legitimized itself with a promise to convene a Sovereign National Conference (a promise which was never fulfilled), the regime proceeded to consolidate itself by co-opting the political class into supporting a 'self-styled' transition programme to civil rule. The same transition was manipulated in such a way that the military was to be perpetuated through transmutation of the Head of State to a civilian president but for the fact that the Head of State died in office before the end of the transition programme. Another political dimension which transition programmes to civil rule had long taken but rarely emphasized is the tendency to use transition programmes to negotiate a "safe exit" for the military either by handing over power to a compromised candidate who will not 'rock the boat', or to hand over power in crisis for another military leader to seize power and continue with the status-quo, or at the extreme, the military leader transforms himself to a civilian president. The anticipated non-confortability of the military with Chief M. K. O Abiola's presidency who was alleged to know the military inside-out was identified as one major reason that informed the military regime of Babangida to annul the June 12, 1993, Presidential election which Abiola won clean and clear. Consequently, the Babangida regime sought for a 'safe exit' elsewhere. This it found in the Interim National Government (ING). The same could be said of General Abubakar's transition programme to civil rule. Most political observers share the opinion that President 
Obasanjo was considered by the military elite a more compromised candidate that can guarantee the military a safe exit than Chief OluFalae who contested against Obasanjo during the 1999 presidential election. The reason for this is not far fetched. Obasanjo with his military background as a retired army General and a former Military Head of State was believed would adhere to the spirit of esprit de corps by covering up the misdeeds and misrule of past military regimes, and possibly proceed to relinquish power to another retired general. On the other hand, Chief OluFalae was considered a threat to the military because of the radical ideology of his political party, the Alliance for Democracy (AD) which the military feared may initiate a probe into its past atrocities. It was therefore not surprising that the majority of the retired Generals including the former Head of State, General Babangida, threw their weight, both morally and financially, behind the People's Democratic Party (PDP), the party under which General Obasanjo (Rtd) contested and won. General Abacha however pushed the safe exit of the military to the extreme by attempting to transform himself to a civilian president.

A new dimension to status-quo maintenance by the military was to handover power in crisis, manifest or potential, which were created by the military itself. This enables the military to stage a come back on the flimsy excuse of the civilian inability to maintain law and order. Such was the situation created by Babangida'stransition programme. Expectedly, the ING lasted only for 82 days as it could not contain the ensued crisis it was supposed to manage. This however, paved the way for General Abacha military regime.

\section{CONCLUSION}

The paper, so far, unveils the programmes of action and actual implementation of transition to civil rule initiated by successive military regimes between 1966 and 1999. More importantly are the politicization, these transition programmes were subjected such that there were varied attempts to transform erstwhile military Heads of State to civilian president during Generals Babangida and Abacha regimes; as well as calculated strategy for "safe exit" for erstwhile military rulers and to handover power in chaos to enable the military stage a come back as experienced during General Babangida transition to democracy.

\section{REFERENCES}

[1]. Achike, O. (1980) Groundwork of Military Law and Military Rule in Nigeria, Enugu: Fourth Dimension Publishers.

[2]. Adekanye (Adekson) B. (1979) 'Dilemma of Military Disengagement" in Oyediran, O. (ed) Nigerian Government and Politics under Military Rule, 1966-1979, London: Macmillan Publishers.

[3]. Awofeso, O. (2000) 'Nigerian Youths and Democratic Stability in the New Millennium: A Socio-Psychological Analysis, Journal of Education and Society, University of Uyo. Vol. 3. No. 1 pp 86-98

[4]. Bennett, V. P. and Kirk-Greene, A. H. M. (1978) "Back to the Barracks: A Decade of Making Time" in Panter-Brick. Keith (ed) Soldiers and Oil: The Political Transformation of Nigeria; London: Frank Cass and Comp. Ltd.

[5]. Campbell, Ian (1978) "Army Reorganization and Military Withdrawal" in Panter-Brick. Keith (ed) Soldiers and Oil: The Political Transformation of Nigeria; London: Frank Cass and Comp. Ltd.

[6]. Dudley, Billy (1982) An Introduction to Nigerian Government and Politics., London: Macmillan Publishers

[7]. _ (1978) Instability and Political Order: Politics and Crisis in Nigeria, Ibadan: Ibadan University Press.

[8]. Oyediran, Oyeleye (1979) (ed) Nigerian Government and Politics under Military Rule, 1966-1979, London: Macmillan Publishers. 